\title{
Relektura eklezjalnego i społecznego znaczenia encykliki Veritatis splendor
}

\begin{abstract}
Thank you for inviting me to share with you this celebration of the $40^{\text {th }}$ anniversary of Karol Wojtyła's election as Pope John Paul II - an event of extraordinary consequence for both the Church and the world. Your conference today, focusing on Veritatis Splendor, reflects that dual importance of John Paul II as a reformer in the Church and as a man with many important things to say about the state of the world and its future. I'd like to talk about this remarkable encyclical in light of those two dimensions of the pontificate: the ecclesial dimension and the public dimension. Let's begin with the ecclesial, or Catholic, dimension of the encyclical.

Why was Veritatis Splendor necessary? Why did John Paul II feel obliged to write an encyclical on the reform of moral theology in the Church?

I think we have to go back to the period immediately after the Second Vatican Council to get the answer to that question. In that period - indeed, while the Council was underway - a new way of doing moral theology, often called "proportionalism," was being developed, largely in the German-speaking Catholic world. According to this theory, the morality of an act should be judged by a calculus of intention and consequence, plus a moral measure of the act itself. And embedded in this theory of proportionalism was the claim that there are no intrinsically evil acts - things that are simply wrong in themselves; what an older moral theology called acts that are malum in se.

This proportionalist theory was part of the Church's great, post-Vatican II debate over the appropriate means of regulating fertility. Pope Paul VI, as you
\end{abstract}


will remember, established a commission to look into questions of family life, birth, natality, etc., and a great argument ensued within that commission. As part of that argument, as many of you will know, Cardinal Wojtyła set up a Cracovian commission to look at these problems. The commission came to the conclusion that, while the traditional teaching of the Church on the appropriate means of regulating fertility should be reasserted in the encyclical, better arguments in favor of that teaching ought to be advanced.

In any event, Paul VI came to understand, during this intense debate in what became known as "the birth control commission," that what was really at stake here was the nature of Catholic moral theology. Those who were pressing for a change in the Church's teaching on the appropriate means of regulating fertility were not just arguing for that particular change. They were attempting to enshrine the proportionalist method of moral reasoning as the official moral theology of the Catholic Church. And Paul VI understood, as Karol Wojtyła understood, that that would be a terrible mistake.

It would be a terrible mistake because it would empty the moral life of all of its drama. If there are no things that are simply wrong in themselves, things that are so humanly degrading that they fundamentally deny the dignity of the human person - if it's all just a matter of balancing intentions and consequences and specific acts - then the moral life loses its drama. And as happened in liberal Protestantism throughout Europe and North America during the second half of the 2oth century, all moral boundaries eventually dissolve.

The proportionalists lost the battle at the time of the writing of Humanae Vitae, but they were determined to continue the war. And it was partially in response to that stubbornness that John Paul II decided to write Veritatis Splendor. There, he tried to restore ballast to Catholic moral theology, not least by asserting the reality of intrinsically evil acts - some things that are just wrong by their very nature, and that no combination of intentions and consequences can make right. Think of sexual assault, think of the torture of children, think of the willful homicide of an innocent person. These things are simply malum in se (as the old language would have it). And to deny that is to empty the moral life of all ballast.

But John Paul II was not simply making philosophical arguments in Veritatis Splendor; he wanted to re-center Catholic moral theology and the Catholic moral life on the Beatitudes.

There's a great misunderstanding in much of the world - especially in the West and even in parts of the Church - that Catholic moral teaching is essentially a laundry-list of do's and don'ts: you can't do this, you can't do 
that, you should do this, you should do that. That is not, as John Paul II wrote in Veritatis Splendor, the nature of the moral life. The Magna Carta of all Christian morality is the Beatitudes. Those eight statements of the Lord in the Sermon on the Mount about human flourishing, human happiness, or what in theological language we would call "beatitude:" they are the framework in which Christians live the moral life. Christians, through the grace of God, seek beatitude. And in seeking beatitude, we are also seeking genuine human flourishing. So, the beatitudes, not rules, are at the center of the moral life in the teaching of Veritatis Splendor.

That doesn't mean there aren't rules. But in Veritatis Splendor and in the thinking of John Paul II, "the rules" are repositioned, or placed in their proper context. Rather than simply being a list of do's and don'ts, and especially don'ts, moral rules become understood as guardrails to guide us on the journey to beatitude. We have moral laws in the Church - we believe that God built moral laws into creation - precisely to lead us on the path to beatitude and to genuine human flourishing. That's what John Paul II tried to do in redirecting moral theology in the Church. He not only taught that the proportionalist method would lead to moral wreckage; he tried to re-center the whole discussion around the question: What are we striving for? What does the grace of God call us to? It calls us to beatitude. It calls us, ultimately, to a life within the communion of the Most Holy Trinity in the Kingdom of God. That's the ecclesial dimension of Veritatis Splendor, if you will.

As for its public dimension, Veritatis Splendor was written at a time when moral language and moral concepts were becoming deeply confused throughout the Western world. What was someone's fundamental human "right" was regarded by others as something intrinsically wrong. There was great confusion over the very idea of freedom. Is freedom merely willfulness? Or does freedom have something to do with truth and goodness?

Remember that in 1993, when Veritatis Splendor was issued, we're only four years away from the fall of the Berlin Wall. New democracies were shaping their public cultures, John Paul II thought it important for the Church to help shape those public moral cultures in ways that they could in turn influence free politics (democracy) and free economics (markets) in a post-communist world.

I think the Pope also had another concern here. John Paul II was deeply marked by the history of the $20^{\text {th }}$ century, which he knew taught us a very valuable lesson. And that lesson is that if morality is simply sentiment - if the moral life is not rooted in truths built into the world and into us, truths that we can know 
by reason - then chaos ensues. Freedom detached from truths easily degrades into license. And a society in which license prevails - a a society in which freedom is detached from truth, in which freedom is not ordered to goodness - is a society heading for deep trouble. Why is that?

If freedom is simply license, if freedom is simply willfulness, then society quickly degrades into a contest of everyone's will-to-power set against everyone else's. I've often explained this to audiences in North America and in Europe in this way: think about it in terms of the collapse of the idea of truth. If there is only "your truth" and "my truth" and neither one of use recognizes some reality called "The Truth," then what happens when your truth and my truth collide, and neither one of us recognizes something called "The Truth" by which we can adjudicate and settle our differences?

What happens, as the philosopher Nietzsche knew, is that you will impose your power on me, or I will impose my power on you. If there is no truth-grounded moral horizon for social life, then society really does decompose into a contest over the will-to-power. That's a kind of Nietzschean nightmare. And because human beings cannot tolerate chaos - the chaos that would ensue from an endless contest of my will to power versus yours - the result of that collapse of morality into sentiment is a chaos that eventually leads to tyranny. People will reach for chains if chains are perceived to be the only alternative to chaos.

Veritatis Splendor tried to address that set of problems by restoring a richer, nobler understanding of freedom to the public life of the West. Here, I think John Paul II drew extensively on the thinking of a Belgian Dominican, moral theologian Fr. Servais Pinckaers, who in his extraordinarily important book, The Sources of Christian Ethics, analyzed the difference between what he called the "freedom of indifference" and what he called "freedom for excellence."

Pinckaers illustrated this difference by asking us to think about two very common human situations. First, learning to play a musical instrument. When I was a boy learning to play the piano, I was given a book called "Scales, Chords, and Arpeggios." It was an awful book-many of you may have known it in your own childhood. It was awful because it forced you to do exercises that trained your fingers to play the piano properly. That seemed terribly restrictive at the time. It seemed like a burden. And yet if you think about it, it is precisely those exercises that allow you to play the music you want to play. It's precisely those exercises that allow you to create new music, because a disciplined understanding of how to play the piano correctly has been learned, has become a habit-and we all know that the old Latin word for "virtue" was habitus. Through those exercises, we've learned the "virtue," the habit, of learning to play the piano properly. 
Contrast that to a three-year-old child simply banging on the piano. You can say that's playing the piano, but it's not a human way of making music; it's a childish, infantile way of making music. Fr. Pinckaers, and John Paul II, would call that the freedom of indifference. That's a freedom without the disciplines that allow us to lead a truly human life commensurate with our human dignity.

Pinckaers offered a second example that I think made a lot of sense to John Paul II, in illustrating this difference between the freedom of indifference and freedom for excellence. Think about learning a new language. Everyone knows that the best way to learn a new language is to speak it, haltingly at first, but in conversation with others. Eventually, though, one has to learn vocabulary and grammar. Grammar and vocabulary are rules. They're rules that allow us to speak a language properly. They're rules that allow us to speak that language so that we can actually communicate with others, so that genuine human community can be formed. That's another example of the difference between the freedom of indifference and freedom for excellence.

The freedom of indifference is my beautiful one-and-a-half-year-old granddaughter, Lucy, babbling. Eventually, though, Lucy is going to have to learn vocabulary and grammar so that she can speak English properly. And that will allow her to live out her human dignity in a much more satisfying way, both for herself and for others.

John Paul II understood that grasping this difference between the freedom of indifference, which is an infantile freedom, and freedom for excellence, which is a mature freedom, was essential for democracy. Democracy is not a machine that can run by itself. It takes a certain critical mass of people living certain virtues to make the machinery of democracy work, so that the net result of democratic politics is social solidarity, the advance of the common good, and the human flourishing of individuals. Getting clear on this distinction between the freedom of indifference and freedom for excellence, which was one of the key teachings of Veritatis Splendor, is thus essential for the future of democracies.

There was another point that John Paul II made in Veritatis Splendor that deserves reflection by people concerned about the democratic future throughout the western world. The Pope posed an interesting question about equality. The equality of human beings - the moral equality and the legal equality of human beings - is a bedrock principle of democracy, he noted. Yet how can we assert that equality in a world in which we are constantly encountering human inequality? Some people are more intelligent than other people. Some people are more beautiful than other people. Some people are more athletically gifted than other people. Some people are more musically gifted or linguistically 
gifted than other people. Some people are great at making money and some people have great entrepreneurial skills; other people can barely balance a checkbook.

How do we assert human equality in a world where inequality is a fact of life we encounter every day? The Pope made an interesting suggestion in Veritatis Splendor. He said the most secure ground on which to assert the fundamental equality of all people, so crucial to democracy, is to recognize the responsibility of every human being before the moral law: before the truths of the moral law that we can know by reason. I think that's a fascinating idea, to ground democratic equality on equal moral responsibility before the truths of the natural moral law we can know by reason. I hope that someday political theorists and political philosophers will take up that proposal and develop it further.

So as you ponder this important encyclical on the 4oth anniversary of John Paul II's election, let me urge you to consider both its importance in the life of the Church, which is being challenged by many today, and its importance in public life. Veritatis Splendor is not an encyclical for the Church alone; it is very much part of the Church's proposal to society at large. And throughout the western world today we are badly in need of that Catholic proposal, which distinguishes the freedom of indifference from freedom for excellence, and which understands that freedom must be tied to truth, and ordered to goodness, if freedom is not to self-destruct.

I greet all of you from here in Washington, D.C. I wish you a good conference. It's always a pleasure to be at the venerable Jagellonian University when I'm in Kraków, and I wish all of you a happy celebration of the $40^{\text {th }}$ anniversary of the election of John Paul II. Thank you for inviting me to join you. 


\section{Hon Jana Pawta II}

Diękuję za zaproszenie mnie do wzięcia udziału w obchodach czterdziestej rocznicy wyboru Karola Wojtyły na papieża Jana Pawła II - wydarzenia o nadzwyczajnych konsekwencjach zarówno dla Kościoła, jak i całego świata. Zorganizowana tu konferencja, skupiona wokół encykliki Veritas Splendor, ukazuje podwójną rolę Jana Pawła II, jako reformatora Kościoła oraz jako człowieka przekazującego wiele ważnych rzeczy o aktualnym i przyszłym świecie. Chciałbym powiedzieć dzisiaj o tej niezwykłej encyklice, przedstawiając ją w dwóch wymiarach: eklezjalnym i społecznym. Zacznijmy więc od kościelnego, czy też katolickiego, wymiaru encykliki.

Dlaczego encyklika Veritas Splendor była konieczna? Dlaczego Jan Paweł II czuł się zobligowany do napisania encykliki na temat reformy teologii moralnej w Kościele? Sądzę, że aby odpowiedzieć na to pytanie, musimy sięgnąć wstecz do okresu tuż po Soborze Watykańskim II. Właśnie wtedy, a nawet w trakcie trwania Soboru, kształtowała się nowa droga realizacji teologii moralnej, zwana często „proporcjonalizmem”, rozwijająca się głównie w niemieckojęzycznej części katolickiego świata. Zgodnie z nową teorią moralność czynu winna być oceniania poprzez analizę intencji i konsekwencji, dodając do niej moralną ocenę samego czynu. Niejako nieodłączną częścią teorii proporcjonalizmu było przekonanie, że nie ma złych czynów samych w sobie - rzeczy złych z natury; takich, które dotychczasowa teologia moralna nazywała malum in se.

Teoria proporcjonalistyczna stała się częścią wielkiej, posoborowej debaty Kościoła dotyczącej właściwych środków regulacji urodzeń. Papież Paweł VI, jak Państwo pamiętają, powołał komisję zajmującą się sprawami życia rodzinnego, kwestią urodzin, przyrostu naturalnego itd. Dało to początek wielkiej dyskusji na łamach tejże komisji. W ramach tej debaty powstała krakowska komisja utworzona przez kardynała Karola Wojtyłę, mająca na celu przyjrzenie się wymienionym problemom. Komisja ta doszła do wniosku, że podtrzymanie tradycyjnego nauczania Kościoła odnośnie do właściwych środków regulacji urodzeń wymaga przedstawienia lepszej argumentacji.

W każdym razie Paweł VI doszedł do wniosku, że w tak intensywnie dyskutowanej kwestii, jaką jest „komisja do spraw kontroli urodzeń”, to, o co rozchodzi się naprawdę, stanowi istotę katolickiej teologii moralnej. Ci, którzy domagali się zmian w nauczaniu Kościoła w zakresie odpowiednich środków regulacji płodności, nie wysuwali argumentów odnośnie do niej samej. Próbowali raczej uświęcić proporcjonalistyczną metodę moralnego rozumowania jako oficjalną teologię moralną Kościoła katolickiego. Zarówno Paweł VI, jak i Karol Wojtyła rozumieli, jak wielkim byłoby to błędem.

Ogrom tego błędu polegałby na tym, że życie moralne zostałoby odarte z całego swego dramatyzmu. Jeśli nie ma rzeczy, które są złe same w sobie, 
rzeczy, które degradują człowieka tak, iż w sposób fundamentalny odbierają godność osobie ludzkiej - jeśli to wszystko staje się kwestią równoważenia intencji, konsekwencji i konkretnych czynów - życie moralne traci swój dramatyzm. I tak, jak to miało miejsce w liberalnym protestantyzmie w Europie i Ameryce Północnej w drugiej połowie XX wieku, prowadzi to do zaniku wszystkich granic moralnych. Proporcjonaliści przegrali debatę w momencie opublikowania encykliki Humanae Vitae, ale z determinacją kontynuowali swoją wojnę. Po części było to powodem, dla którego Jan Paweł II zdecydował się napisać Veritatis Splendor. Próbował w niej przywrócić wagę katolickiej teologii moralnej, zwłaszcza poprzez podkreślenie istnienia czynów wewnętrznie złych - rzeczy, które są niewłaściwe w samej swej naturze i żadna kombinacja intencji i konsekwencji nie uczyni ich właściwymi. Pomyślmy tu o wykorzystaniu seksualnym, znęcaniu się nad dziećmi, świadomym zabijaniu niewinnych ludzi. Rzeczy te są po prostu (i w dawnym języku były) malum in se. Zaprzeczanie temu to zdjęcie z życia moralnego całego jego balastu.

Encyklika Veritatis Splendor nie przedstawiała jedynie filozoficznych argumentów. Jan Paweł II chciał przywrócić centrum uwagi katolickiej teologii moralnej i moralnego życia, koncentrując ją na Błogosławieństwach.

Istnieje, i to w dużej części świata nawet obecnie, ogromne niezrozumienie katolickiego nauczania moralnego, sprowadzając je do żmudnej listy zakazów i nakazów: nie wolno ci tego, nie wolno ci tamtego, powinieneś to, powinieneś tamto. Natomiast Magna charta [Wielką Kartę Swobód (obywatelskich)] moralności chrześcijańskiej stanowią Błogosławieństwa. Te osiem zdań, wypowiedzianych przez naszego Pana w Kazaniu na górze, mówiących o ludzkim odrodzeniu, ludzkiej szczęśliwości lub, jak nazywamy w języku teologicznym, „błogosławieństwie”, stanowi podstawę, na której powinni opierać się chrześcijanie wiodący moralne życie. Chrześcijanie poszukują błogosławieństwa poprzez Bożą łaskę. W tym poszukiwaniu szukają także prawdziwego ludzkiego szczęścia. Tak więc to nie reguły, ale błogosławieństwa stanowią centrum życia moralnego w nauczaniu według Veritas Splendor ${ }^{114}$.

Nie oznacza to, że nie ma reguł. Ale w encyklice Jana Pawła II i w jego myśleniu następuje transponowanie „reguł”. Lista zakazów i nakazów, a zwłaszcza zakazy, zasady moralne zaczynają być traktowane jak poręcze wspierające w drodze do błogosławieństwa. Mamy prawa moralne w Kościele - i wierzymy, że Bóg ustanowił te prawa jako część naszego stworzenia - właśnie po to, aby prowadziły nas one na ścieżce prowadzącej do błogosławieństwa i prawdziwego szczęścia. To właśnie próbował przekazać Jan Paweł II, kiedy mówił 
o przekierowaniu teologii moralnej Kościoła. Nie uczył tylko, że metoda proporcjonalistyczna doprowadzi do katastrofy moralnej, ale próbował przywrócić centrum uwagi całej dyskusji, skupiając je wokół zagadnienia: Do czego dążymy?, Do czego wzywa nas łaska Boża? Wzywa nas ona do szczęśliwości. Wzywa nas docelowo do życia w komunii z Trójcą Przenajświętszą w Królestwie Bożym. Taki jest, pozwolę sobie stwierdzić, eklezjalny wymiar encykliki Veritatis Splendor.

Jeśli chodzi o jej społeczny wymiar, została ona napisana w czasie, kiedy w zachodnim świecie zaczęło następować całkowite pomieszanie pojęć i koncepcji związanych z moralnością. To, co stanowiło czyjeś fundamentalne ludzkie prawo, przez innych traktowane było jako coś dogłębnie złego. Nastąpiło przeogromne pomieszanie idei wolności. Czy wolność jest jedynie samowolą? Czy ma ona coś wspólnego z prawdą i dobrem?

Pamiętajmy, że w roku 1993, kiedy opublikowano encyklikę Veritatis Splendor, minęły zaledwie cztery lata od upadku muru berlińskiego. Ponieważ nowo powstałe demokracje kształtowały kulturę społeczną, Jan Paweł II uznał za ważne, aby Kościół wspomógł kształtowanie moralnej kultury społecznej w taki sposób, by ta z kolei mogła wpływać na wolność polityczną, demokrację oraz wolną gospodarkę w postkomunistycznym świecie.

Myślę, że również coś innego budziło obawy Jana Pawła II. Był on głęboko naznaczony historią XX wieku i wiedział, że powinna ona dawać cenną lekcję. Lekcję o tym, że jeśli moralność pozostaje tylko sentymentem - jeśli moralność nie jest zakorzeniona w prawdach wbudowanych w świat i w nas samych, prawdach, które poznajemy rozumem - następuje chaos. Wolność oddzielona od prawdy szybko staje się jedynie przyzwoleniem. I społeczeństwo, w którym dominuje przyzwolenie, w którym wolność oddziela się od prawdy, w którym wolność nie jest skierowana na dobro, staje się społeczeństwem zmierzającym ku poważnym problemom. Dlaczego tak jest?

Jeśli wolność jest tylko przyzwoleniem, jeśli jest ona tylko samowolą, społeczeństwo szybko zostaje zdegradowane do rywalizacji jednych, mających wolę mocy, przeciwko drugim. Często tłumaczę to moim amerykańskim i europejskim słuchaczom w następujący sposób: pomyślcie o tym w kategoriach załamania się idei prawdy. Jeśli istnieje tylko „twoja prawda” i „moja prawda” i żaden z nas nie uznaje pewnej rzeczywistości zwaną „Prawdą”, co się stanie, gdy twoja i moja prawda zderzą się i żaden z nas nie uzna tego, co nazywamy „Prawdą”, według której możemy rozstrzygnąć i pogodzić dzielące nas różnice.

O tym, co nastąpi, wiedział już Nietzsche. Niemiecki filozof mówił, że jeśli ty narzucisz twoją wolę mocy mnie, ja narzucę swoją wolę tobie. Jeśli w życiu społecznym zabraknie moralnej linii horyzontu, wspartej na prawdzie, społe- 
czeństwo będzie jedynie walczyć o wolę mocy. Na tym polega rodzaj nietzscheańskiego koszmaru. I ponieważ istoty ludzkie nie tolerują chaosu - chaosu, jaki byłby następstwem nieustannej walki o dominację mojej woli nad twoją - skutkiem sprowadzenia moralności do poziomu sentymentu byłby chaos, prowadzący ostatecznie do tyranii. I ludzie sięgną po łańcuchy, jeśli zobaczą w nich jedyną alternatywę dla chaosu.

Encyklika Veritatis Splendor próbuje zmierzyć się z tymi problemami poprzez przywrócenie głębszego, wznioślejszego rozumienia pojęcia wolności w życiu publicznym Zachodu. Myślę, że Jan Paweł II wyraźne nawiązuje w niej do myślenia belgijskiego teologa moralnego ojca Servais'go Pinckaersa. W swej niezwykle ważnej książce, The Sources of Christian Ethics ${ }^{115}$, belgijski dominikanin analizuje różnice pomiędzy tym, co nazywamy „wolnością obojętną na wartości” a „wolnością do doskonałości”"116.

Ojciec Pinckaers ilustruje tę różnicę, prosząc nas, abyśmy rozważyli dwie typowo ludzkie sytuacje. Pierwsza to nauka gry na instrumencie muzycznym. Kiedy byłem chłopcem i uczyłem się gry na pianinie, dostałem książkę pt. Scales, Chords, and Arpeggios [Gamy, akordy, arpeggia]. To była straszna książka - wielu z Państwa być może zna ją z własnego dzieciństwa. Była okropna, ponieważ zmuszała do ćwiczeń palców, aby potem móc dobrze grać na pianinie. $\mathrm{W}$ tamtym czasie wydawało się to szalenie restrykcyjnie. Było jak ciężar. Ale jeśli to przemyśleć, były to najodpowiedniejsze ćwiczenia, które pomagały zagrać tak, jak byśmy sobie tego życzyli. Były to najlepsze ćwiczenia pozwalające tworzyć nową muzykę, ponieważ przyjęta dyscyplina w nauce poprawnej gry na pianinie stała się nawykiem - a wszyscy znamy stare łacińskie słowo habitus, które znaczy tyle, co „cnota”. Posiedliśmy więc cnotę uczenia się właściwej gry na pianinie.

Zestawmy to teraz z bębnieniem trzyletniego dziecka w klawiaturę. Można powiedzieć, że jest to gra, ale nie jest to ludzki sposób tworzenia muzyki; to jest dziecinna, infantylna muzyka. Ojciec Pinckaers i Jan Paweł II nazwaliby to wolnością obojętną. To znaczy wolnością pozbawioną dyscypliny, która nie pozwala nam wieść prawdziwie człowieczego życia, odpowiadającego naszej ludzkiej godności.

Ojciec Pinckaers podaje również inny przykład ilustrujący różnicę pomiędzy wolnością obojętną a wolnością do doskonałości, który według mnie bardzo przemawiał do Jana Pawła II. Pomyślmy o nauce nowego języka. Każ-

${ }_{115}$ S. Th. Pinckaers OP, Źródła moralności chrześcijańskiej. Jej metoda, treść, historia, tłum. A. Kuryś, Poznań 1994.

116 Por. S. Th. Pinckaers OP, Źródła moralności..., dz. cyt., s. 302-341. 
dy wie, że najlepszym sposobem nauki języka obcego jest mówienie w nim, na początku w sposób łamany, ale rozmawiając z innymi. Wreszcie - trzeba nauczyć się słówek i gramatyki. Gramatyka i słownictwo to zasady. Zasady, które pozwalają nam mówić poprawnie w danym języku. Są to zasady, które pozwalają nam komunikować się z innymi ludźmi. Jest to inny przykład pokazujący różnicę pomiędzy wolnością obojętną a wolnością do doskonałości.

Wolność obojętną uosabia moja półtoraroczna, paplająca wnuczka Lucy. W końcu będzie musiała się nauczyć słów i gramatyki, aby mówić poprawnym angielskim. Pozwoli jej to przeżyć życie z ludzką godnością w bardziej satysfakcjonujący sposób, zarówno dla niej samej, jak i dla innych.

Jan Paweł II wiedział, że zrozumienie różnicy pomiędzy wolnością obojętną, która jest wolnością infantylną, a wolnością do doskonałości, która jest wolnością dojrzałą, jest istotna w demokracji. Demokracja to nie maszyna, która może chodzić sama z siebie. Aby maszyna demokracji mogła działać, potrzeba pewnej znaczącej masy ludzi, żyjących według pewnych wartości tak, aby wynikiem netto polityki demokratycznej była społeczna solidarność, wzrost dobra wspólnego oraz pomyślności poszczególnych jednostek. Dokonanie klarownego rozróżnienia pomiędzy wolnością obojętną a wolnością do doskonałości to jedna z kluczowych nauk płynących z encykliki Veritatis Splendor ${ }^{117}$, jest to zatem istotne dla przyszłości demokracji.

Inną kwestią, poruszoną w Encyklice Jana Pawła II, która zasługuje na uwagę ludzi zatroskanych przyszłością demokracji w zachodnim świecie, jest interesujące zagadnienie równości. Papież zaznacza, że równość istot ludzkich - ich moralna i prawnie ustanowiona równość - stanowi fundamentalną zasadę demokracji. Jakże możemy twierdzić, iż istnieje równość na świecie, jeśli nieustannie promujemy nierówność? Niektórzy ludzie są bardziej inteligentni od innych. Niektórzy piękniejsi od innych. Niektórzy silniejsi fizycznie. Niektórzy bardziej uzdolnieni muzycznie lub językowo. Niektórzy mają talent do robienia pieniędzy, wykazują duże zdolności przedsiębiorcze, podczas gdy inni ledwo bilansują rachunki.

Jakże możemy zapewniać, że istnieje równość między ludźmi, kiedy stykamy się z nierównością każdego dnia? Jan Paweł II przedstawia bardzo interesującą propozycję w swojej encyklice. Mówi, że najpewniejszym gwarantem równości wszystkich istot ludzkich, tak ważnej dla demokracji, jest uznanie odpowiedzialności każdego człowieka przed prawem moralnym: przed prawdami moralnymi, które możemy poznać rozumowo ${ }^{118}$. Myślę, że jest to fascynują-

${ }_{117}$ Por. Jan Paweł II, Veritatis Splendor..., dz. cyt., nr 48-53.
${ }_{118}$ Por. Jan Paweł II, Veritatis Splendor.., dz. cyt., nr 95-101. 
ca idea, by oprzeć demokratyczną równość na moralnej odpowiedzialności przed prawdami naturalnego prawa moralnego, jakie poznajemy rozumem. Mam nadzieję, iż pewnego dnia polityczni teoretycy i filozofowie podejmą tę ideę, aby ją dalej rozwijać.

W rozważaniu tak ważnej encykliki $\mathrm{z}$ okazji czterdziestej rocznicy wyboru Jana Pawła II chciałbym namówić Państwa do zastanowienia się nad jej znaczeniem dla życia Kościoła, obecnie tak często atakowanego, oraz jej znaczeniem w życiu społecznym. Encyklika Veritatis Splendor nie jest encykliką adresowaną tylko do Kościoła; jest w dużej mierze propozycją Kościoła dla wolnego społeczeństwa. I w naszym zachodnim świecie bardzo czekamy dziś na taką propozycję. Propozycję rozróżnienia pomiędzy wolnością obojętną a wolnością do doskonałości, która przyjmuje, że wolność musi być zespolona z prawdą i skierowana na dobro, jeśli nie ma prowadzić do autodestrukcji.

Pozdrawiam wszystkich z Waszyngtonu, życząc udanej konferencji. Zawsze, kiedy jestem w Krakowie, z ogromną przyjemnością odwiedzam szacowny Uniwersytet Jagielloński. Składam Państwu najserdeczniejsze życzenia z okazji czterdziestej rocznicy wyboru Jana Pawła II. Serdecznie dziękuję za zaproszenie.

(tłum. Agnieszka Stańczyk) 
Słowa klucze: Jan Paweł II, Veritatis splendor, nauczanie o Kościele, nauka społeczna Kościoła, reguły życia, jest to nauczenie także dla całego świata nie tylko chrześcijańskiego

Streszczenie: Artykuł ukazuje podwójną rolę Jana Pawła II, jako reformatora Kościoła oraz jako człowieka przekazującego wiele ważnych rzeczy o aktualnym i przyszłym świecie. Encyklika Veritatis splendor przedstawiona została w dwóch wymiarach: eklezjalnym i społecznym. Encyklika Veritatis Splendor nie przedstawiała jedynie filozoficznych argumentów. Jan Paweł II chciał przywrócić centrum uwagi katolickiej teologii moralnej i moralnego życia, koncentrując ją na Błogosławieństwach. W rozważaniu tak ważnej encykliki $z$ okazji czterdziestej rocznicy wyboru Jana Pawła II autor chce namówić do zastanowienia się nad jej znaczeniem dla życia Kościoła, obecnie tak często atakowanego, oraz jej znaczeniem w życiu spotecznym. Encyklika Veritatis Splendor nie jest encyklika adresowana tylko do Kościota; jest $w$ dużej mierze propozycja Kościoła dla wolnego społeczeństwa. I w naszym zachodnim świecie bardzo czekamy dziś na taka propozycję. Propozycję rozróżnienia pomiędzy wolnościa obojętna a wolnościa do doskonałości, która przyjmuje, że wolność musi być zespolona z prawda i skierowana na dobro, jeśli nie ma prowadzić do autodestrukcji.

\section{Re-pondering the ecclesial and social significance of encyclical Veritatis splendor}

Key terms: John Paul II, Veritatis splendor, Church teachings, social teachings of the Church, moral life, teaching also for the entire, not only Christian world

Abstract: The article exhibits a double role of John Paul II, as a reformer of the Church and as a man conveying many essential things about the contemporary and future world. Encyclical Veritatis splendor has been presented in two dimensions: ecclesial and social. The Encyclical was not offering merely philosophical arguments. John Paul II wanted to re-center Catholic moral theology and the Catholic moral life on the Beatitudes. In pondering this important Encyclical on the occasion the $40^{\text {th }}$ anniversary of John Paul II's election the author wants to urge us to consider both its importance in the life of the Church, which is being challenged by many today, and its importance in public life. Veritatis Splendor is not an encyclical for the Church alone; it is very much part of the Church's proposal to society at large. And throughout the western world today we are badly in need of that Catholic proposal, which distinguishes the freedom of indifference from freedom for excellence, and which understands that freedom must be tied to truth, and ordered to goodness, iffreedom is not to self-destruct.

DOI: http://dx.doi.org/10.15633/9788374388306.11 
4. Uniwersytet Papieski

Jes Jana Pawła II

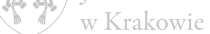

